
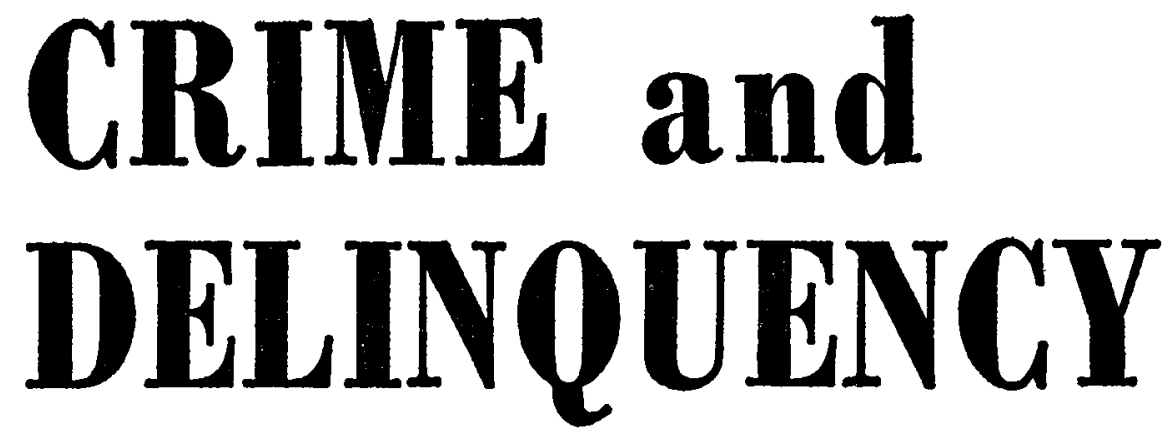

NATIONAL COUNCIL ON CRIME AND DELINQUENGY

Volume 15

April 1969

Number 2

\title{
Wanted: A Balanced System of Justice
}

\author{
William T. Downs
}

Coordinator, Inter-Faith Action Centers, Detroit

Judge, Charlevoix County Probate Court, Charlevoix, Mich., 1958-60; Deputy Court Administrator, State of Michigan, 1961-63

B.A., 1941, University of Michigan; J.D., 1948, University of Michigan Law School

Under a slightly ruffled surface, the legal system is in ferment. National focus on the plight of the indigent defendant, the void in legal services for the poor, the dearth of treatment facilities, and antiquated correctional systems have converged with significant impact on the staid and settled ways of the justice system. Suggestions considered outright heresy a few years ago are today regarded only as unorthodox.

The sincere and prompt response to some of these problems by persons in the justice system is commendable. The hazard lies in single-purpose reforms. The inequity is not that the poor must wait years for trial, but that anyone must wait; not that the poor receive no capable and effective representation, but that anyone is denied such representation; not that the well-connected can negotiate invisible compromise, but that any decisions are invisible.

The situation demands an analysis of the legal process which recognizes that the system is composed of interrelated parts and which tries to secure a balance between community and individual interests. 
7 WHE MAN ON THE SUBWAY reading his evening newspaper shakes his head when he reads statistics of increasing crime. He mentally condemns the police, the law, and the courts. As his eye picks up a story of a recent mugging or robbery, he wonders whether that offender will be caught and convicted. Cynically, he concludes that some shrewd lawyer will get the offender off or that some political judge will slap the offender on the wrist and release him. This average man visualizes a simple criminal justice system; he automatically associates arrest, trial, conviction, and correction. A few professionals in the field now agree with this perspective; they regard criminal justice as a continuum from arrest to parole. This article will attempt to isolate some of the basic issues by regarding the administration of criminal justice as just such a total system.

Much confusion and controversy is caused by the failure to separate different levels and kinds of issues, resulting in much time and energy expended on the symptoms of problems instead of the basic issue. For instance, if we regard the overcrowding of court calendars and the delay of hearings as primary issues, we are likely to think that the solution is extended hours for the court and additional judicial personnel. ${ }^{1}$ Or, if we focus on overcrowding of jails and the resulting deplorable conditions, we might believe that bail release programs or jail clean-up campaigns are the answer. We would, however, merely be treating symptoms. On the other hand, if we deal with the larger

1 The Ford Foundation points out that in Washington, D.C., a 25 per cent increase in judges has resulted in only a 3 per cent improvement in lapsed time from arrest to disposition. issue of malfunction of the system, evidenced by overcrowding of court calendars and delay of hearings resulting in jail congestion, we will solve many symptomatic problems.

\section{Entry into the Legal System}

The President's Crime Commission reports that more than 50 per cent of offenders who enter the system have committed what it terms "crimes without victims." These offenses, such as drunkenness, drug use, and prostitution, present cases which "clog the lower courts and crowd city and county jails."2

Many people believe acts of this kind should not be defined as crimes because (l) from a medical point of view, these acts are symptoms of a disease; (2) the acts reflect standards of individual moral conduct and are not offenses against the public or individual members of society; (3) probably only a small proportion of the population considers acts of this kind criminal, ${ }^{3}$ although it might deem them morally wrong; (4) the judicial system is incapable of providing effective treatment for persons who commit such acts; (5) the burden these persons place on the system impedes the administration of justice for more serious offenses. ${ }^{5}$ Defining

2 The Challenge of Crime in a Free Society, A Report of the President's Commission on Law Enforcement and Administration of Justice (G.P.O.: Washington, D.C., 1967), p. 5 .

3 Nathan Hare, "The Ambivalent Public and Crime," Crime and Delinquency, April 1963 pp. 145-51. See also "Model Neighborhood Program" (City of Detroit Model Neighborhood Agency), Part I: Problem Analysis, submitted Dec. 23, 1968, to the Department of Housing and Urban Development.

4 Task Force Report: The Courts (G.P.O.: Washington, D.C., 1967), ch. 8, p. 97.

6 The Challenge of Crime in a Free Society, supra note 2, p. 235. 
these acts as crimes also perpetuates abuse and corruption. I believe these offenses should be removed from the criminal statutes.

Other solutions exist besides statutory revision. Since the police are empowered to exercise discretion in arrests, this discretion could conceiva. bly be extended by a policy precluding the arrest of persons in this category. ${ }^{\circ}$

The establishment of an "adult service center" in every community is another solution. For some time the establishment of "youth centers" to treat delinquent youths whose acts do not warrant juvenile court proceedings has been favored. Why does the same logic not apply to this category of adult offenders? By establishing adult centers we could offer treatment to correct the behavior of the offender. Behavioral scientists generally agree that coercion is unnecessary and contributes little toward ultimate correction. Flexible procedures could be established by the adult center, including the initiation of court proceedings when necessary. A procedural redefinition of this kind could cut the caseload of the criminal justice system's lower portion in half. This would go a long way toward remedying congestion and the other ills asso. ciated with that problem.

The adult center would explore the offender's life, discover his problems, and begin to solve them. Both inmate and outmate care should be included to prescribe treatment according to individual need rather than kind of offense. It should provide comprehensive service under a single administrative direction, crossing professional and organizational lines. The center

6 St. Louis, Mo., operates a detoxification center in a beginning application of this concept, would thus become a diagnostic and screening device for the discovery and treatment of disease and handicaps, and problems of mental health, welfare, education, and employment. I think such an approach would be more effective with this particular group than the separate manpower, health, and neighborhood centers, each with its own case finding and screening staff and services.

\section{Differentiation among Offenders}

Just as we must reconsider the criteria for entry into the criminal justice system and redefine criminal acts, we must also differentiate among classes of offenders. I do not mean individual offenders, but categories such as organized crime, individual crime for profit, and accidental offenses.? Opinions will differ about nomenclature and about the dividing lines between categories, but the important thing is for the system to recognize that these classes do exist and to acknowledge that it may process the different classes in different ways.

Johnny Jones has a few beers, breaks into the Monza Shop, takes a $\$ 350$ motorcycle, and goes for a joy ride. Jimmy Jones breaks into the Grand Prix Shop and steals a $\$ 350$ cycle; he is a member of a ring which steals motorcycles, strips and repaints them, and resells them through a distribution system in another state.

If the two are apprehended, the system treats them identically. True,

7 An "accidental offender" is a person who commits an offense through force of circumstances. The largest proportion of members of this category is made up of juveniles who follow the ringleaders of their group in perpetrating a crime but are not the actual instigators. Another "accidental offender" is a person who is made desperate by a series of personal misfortunes and turns to crime as the only immediate solution to his problems. 
actual sentences may differ, because persons within the system may realize the difference in the circumstances. The point is, should sentences depend upon individual views, attitudes, and training? Should not the system itself differentiate among the major groups of offenders?

In one sense we are doing this when we create special police units to deal with organized crime and when we acknowledge that wire tapping is permissible in matters of organized crime and national security. These isolated examples are responses to specific situations. The entire system should be surveyed to determine which procedures designed for the protection of the average citizen are not really appropriate for a member of a crime organization. We may discover that different rules should be established for arrest and interrogation, for bail and release, for pretrial procedures, for conduct of hearings, and for sentencing and correction. Although my opinion borders on heresy, I do not accept without question the current assumption that identical procedures must be used in every case. Change always entails some risks, which must be analyzed and provided with safeguards, but their presence should not foreclose inquiry.

\section{Safeguards within the System}

The U.S. Supreme Court has recently delivered a number of decisions (Mallory, Miranda, Escobedo, Gideon, Kent, and Gault ${ }^{8}$ ) dealing with the application of the due proc-

8 Mallory $v$. United States, 354 U.S. 449 (1957) ; Miranda v. Arizona, 384 U.S. 436 (1966); Escobedo v. Illinois, 387 U.S. 478 (1964); Gideon v. Wainwright, 372 U.S. 335 (1963); Kent v. United States, 383 U.S. 541 (1966); In re Gault, 387 U.S. I (1967). ess clause, which provides a concept of fairness to the accused. Many of the rulings provoked a storm of protest and controversy. The controversy arose because to some people the cases represent an extension of constitutional protection; to some they represent hindsight about circumstances, the implications of which could not have been foreseen; to others they represent a threat to law and order (in some instances the decision actually effected the release of an admitted criminal because of an administrative decision against a retrial).$^{9}$ The protest arose not against the Supreme Court decision, but because of hasty, ill-advised, or imprudent interpretation of the rulings in matters then pending before a trial court.

If the criminal justice system is compelled to deal with each individual set of circumstances such as those in the Miranda or Escobedo cases, we will have endless litigation, infinite overcrowding of our court calendars, tiresome delays in proceedings, jail crowding, police uncertainty, and continuing controversy. These decisions address two fundamental issues piecemeal: (1) Are we to permit invisible decisions in the criminal process? (2) Are we to continue to rely on the exclusionary rule for discipline of the police?

\section{INVISIBILITY}

One of the more important issues of the concept of "fairness" enunciated by the Supreme Court is suspicion of any step in the criminal process that is held in private, invisible to the general public or to anyone outside the system. This legitimate

O Dan H. McCullough, "The Rights of the Accused and the Public," American Bar As. sociation Journal, March 1968, pp. 273-78. 
suspicion should concern every citizen. It is a recognition of certain common human traits: people behave differently in private from the way they do in public; a person can become so well convinced of one side of a question that he will unconsciously exclude consideration of contrary or contradictory facts or circumstances; only the very unusual person does not enjoy an advantage of power over another individual.

This suspicion also acknowledges that organizations form and pursue their own goals and objectives; that such goals and objectives might not be in the interest of the accused; that organizational objectives are not likely to be consistent with the goals of any individual member of that organization. An organization tends to protect itself and to compete with other organizations, consequently trying to achieve a successful record. Large organizations find it difficult to ensure that policies are carried out uniformly throughout the entire structure. These facts of life about individuals and organizations in general apply in particular to policemen and law enforcement organizations.

How do you then protect the citizen from malfunctions and misfunctions of the system? The Supreme Court may be saying that one way is to prohibit, as much as possible, all invisible proceedings. This ban raises serious questions about any kind of so-called informal proceedings, which are sometimes proposed with the good intention of simplifying the process. The court's decisions strongly suggest that any informal proceeding must not be so informal as to exclude objective scrutiny of that proceeding.

The traditional way of removing this cloak of invisibility is to insist on the presence of an attorney. This is what the Supreme Court has been directing. In some circumstances this may result in "overkill," the investment of more talent and more qualification than is required in the given situation. Although some circumstances necessitate the expertise of a lawyer to provide adequate protection for the individual, often he is not needed. In many cases, the presence of an objective observer may meet the requirement for visibility and also provide adequate protection. Here is an opportunity to develop paraprofessional roles in the law. Trained personnel could improve the quality of justice while relieving the shortage of professional lawyers. They would be directed by professional attorneys as aides to appointed or assigned counsel for indigent defendants or as auxiliaries to public defenders.

\section{Exclusionary Rule}

The exclusionary rule is one of the peculiarities of the American system of justice. It means the exclusion of evidence that has been erroneously admitted, such as physical evidence obtained in an illegal search and seizure, and possibly the dismissal of the case. This rule acts as a disciplinary force on the police. ${ }^{10}$ The justification most frequently offered by the courts when the accused in a specific case goes free-that it is a caution to the police to behave differentlyshould be carefully scrutinized. Many people have long been dubious of the rule's effectiveness on police action. A recent Georgetown University Law Center study of the effects of Miranda on the practices of the District of Columbia police department reveals that, during the ten months following

10 Task Force Report: The Police (G.P.O.: Washington, D.C., 1967), p. 31. 
the decision, little or no change was made.11

Again, we could attack the symptoms by criticizing the police, insisting on more highly educated police officers and planning short-term police-training programs. A better approach is to question the exclusionary rule as an effective way of directing police action. No administration links the court and police systems. Rarely does any joint policy-making apparatus or administrative machinery enable the court to direct revision or modification of police policies or practices. $^{12}$ No internal supervisory coalition deals with the simple issues of who hires and fires, who promotes and reprimands, and who supervises and directs. The lines of authority are too tenuous. That anyone really believes such a system can work seems incredible. The unworkability of the arrangement is an important cause of "role distortion" by police and judges; the result is police who would judge ${ }^{13}$ and judges who would police. A court decision is based on the individual facts of a specific case and is not concerned with considerations pertinent to policy statements. ${ }^{14} \mathrm{We}$

11 Richard J. Medalie et al., "Custodial Police Interrogation in Our Nation's Capital: The Attempt to Implement Miranda," Michigan Law Review, May 1968, p. 1347.

12 Cf. Herman Goldstein, "Trial Judges and the Police-Their Relationship in the Administration of Criminal Justice," Crime and Delinquency, January 1968, pp. 14-25.

13 See the Detroit Free Press, Jan. 8, 1969, p. 2, where Carl Parsell, president of the Detroit Police Officers Association, is quoted as saying that a recent press headline, "Negro Youth Leader Killed," should have read, "Police Rid City of Rapist."

$14 \mathrm{~A}$ closely related question is appeal by the prosecution. When an individual case serves the dual purpose of deciding the fate of the defendant and setting a standard for police policy and practice, simple logic demands that appeals be permissible on the must consider and explore alternatives providing for participation of the judiciary in the formulation of policy guidelines for the police. ${ }^{15}$ I disagree with those who think this policy formulation should be a declaratory judgment as in the civil process, and with those who object that such participation would be a prejudgment of issues. Participation in and formulation of policy guidelines is entirely different from prejudging a specific case, for the court will still objectively review specific cases.

The ambiguity of the present system is frustrating for the police and creates a serious morale problem, ${ }^{16}$ which in turn creates problems for the community. The extent to which police officers see the courts as their opponents or enemies is alarming. No system can long function with this kind of conflict, where people will follow devious routes to frustrate one another. In such a situation, there can be no winner, and the loser is the public. No matter what the theoretical situation is, we must deal with the way the police see themselves and the way they see the courts.

Court administration is one possible device for police policy guidance. Another possible solution is joint committees consisting of representatives of the police, prosecution, courts, and correction. The advantage of this solution is that it recognizes criminal justice as a system composed of separate parts. The com-

latter matter. A procedure for appeal should be devised that does not jeopardize the defendant.

15 The Challenge of Crime in a Free Society, supra note 2, p. 106.

16 The situation is exacerbated when the police agency is in a multi-judge court and the judges disagree about application of the exclusionary rule. 
mittee structure would also make possible the addition of citizen members, where advisable. This kind of citizen participation is consistent with our ideals of democracy, our concepts of justice; it is urgently needed. The function of the jury is to temper the law, to acknowledge human frailty, and to apply a community standard of behavior. The committee suggestion provides an additional opportunity for such a citizen function. Perhaps a joint plan is feasible, using the committee structure for the development of the guidelines, and the court administrator's office for the implementation.

\section{Concept of Law Enforcement}

A fundamental issue which cannot be treated in court decisions, but which nevertheless underlies all issues in the system, is the concept of law enforcement, presently obscured by racial undertones. The lack of such a concept greatly contributes to the confusion in the criminal justice system. Do not hastily condemn the citizen as apathetic; we have not provided the structures enabling him to form his concept and have it applied. The legislative process in today's complex government is too far removed from the public. As a result, autocratic organization administers democratic precepts. This situation must be changed. A measure of democratic control must be reasserted over government operations, including the police.

The absence of a specific concept forces the law enforcement agencies to satisfy a variety of sometimes opposing public demands. No police department can fulfill expectations of tolerance and permissiveness on one hand and rigid control on the other.

The courts have emphasized respect and dignity for the individual in whatever capacity the police may be acting. Although such action is desirable and commendable, it again treats the symptom instead of the cause. We must create methods for citizen participation in the actual formulation of law enforcement concepts and policies.

I urge the public to regard law enforcement as the preservation of order, for this is our immediate and continuing concern. In our most urgent situation at present, civil disorder, preservation of order means that once the disturbance has been quelled, the primary goal of society has been achieved. Detention, prosecution, and conviction become a separate issue and should be regarded as measures to maintain order in the future. The question then arises whether any corrective action taken in a court proceeding will actually be a deterrent to the future behavior of the defendant or of others. Often no action may be necessary beyond the immediate step of resolving the disturbance. Sometimes further action may actually encourage future disorder rather than deter it. If so, society's goal of maintaining order is completely contrary to authority's concept of vindication and conventional punishment. I say conventional because incarceration habitually is considered the only method of punishment and deterrence.

\section{Flexible Response}

If our primary interest is in maintaining order, we must control the behavior of our citizens. Most people behave in an acceptable fashion because of a variety of internal controls. People violate the law and make society exert overt control for many different reasons. The norms or 
laws may be unreasonable and improper, or unsupported by a majority of society. The clearest example of the latter category is sexual behavior, where the laws are much more restrictive and stringent than the prevailing attitudes of most of the population. ${ }^{17}$ If the violation is the fault of the violator rather than the law, and our objective is to control individual behavior, effective control must relate to the reason for the violation.

The basis of the present criminal law is that incarceration is the only ultimate penalty. The President's Commission says it is convinced that "it is undesirable that offenders travel any further along the full course from arrest to charge to sentence to detention than is absolutely necessary for society's protection and the offenders' own welfare."18 The force of this statement is diminished by the rest of the report, which does not seem to recognize the correctional effect of the judicial process itself. The system presumes that a correctional disposition is necessary in every case. This attitude is derived from the law, administrative procedures, and human reactions. The average judge feels, consciously or unconsciously, that he must recommend correction as a justification for himself and his profession, because the public expects him to "do something." Doing something means imposing a sentence.

Abundant evidence shows that incarceration is not universally effective, as proven by high recidivism rates. Recognition of this fact has resulted in a number of programs usually described as alternatives to institutionalization, including probation, work release, and weekend jail. The

17 Cf. Illinois Criminal Code of 1961.

18 The Challenge of Crime in a Free Society, supra note 2, p. 14. flexibility permitted through probation is essentially a degree of incarceration; the remedy is still prison if the conditions of probation are violated. Probation is thought to work because it contains this possible restriction of liberty. Little proof, however, is found of the supposed effectiveness of probation. The studies attesting to its worth do so by comparing it to incarceration. In other words, the studies do not show probation to be good but only that it is less bad than prison. Studies should be made comparing probation to no supervision at all. In some cases, correctional treatment may not even have to be imposed.

No matter how commendable the other alternatives to incarceration may be, they are still based on the same erroneous assumption: that imprisonment is the only effective penalty. We must recognize the fallacy of that assumption, and build our theory, our laws, and our practices toward the goal of changing behavior, not punishing it. We must treat the reason for the crime (the basic issue), not only the crime itself (the symptom). We must devise a flexible system of reward and punishment geared to achieving behavioral change.

\section{Other People in the System}

The nature of the criminal process and preoccupation with the rights of the accused have distorted our view of the system. While there is ample justification for our concern with the rights of the accused and, at a later stage, with the convicted, this very emphasis obscures the rights of the others involved in the system.

The general public view of the system is shaped by contacts with it in a role other than as a defendant. Not only the police but persons in all parts of the system are involved with 
the public. Practices and procedures frequently appear to the citizen to be made solely for the convenience of those administering the system.

We must express consideration for the victim and for the witnesses in positive and constructive ways, not by attacking or diminishing the rights of the accused: the two matters are separable. Considerable attention is focused on the well-being and comfort of the accused, while the witnesses are ignored or treated cavalierly. Besides receiving ordinary consideration, witnesses and victims should be subjected to a minimum of intrusions and interruptions of their daily routine. Recently a loud clamor arose about detention of a suspect for questioning; a crime bill in Washington, D.C., authorizes a three-hour limit. Yet, many witnesses are detained for six, eight, or twelve hours without explanation and are then told to return at another time to wait some more.

The President's Commission points out the great disparity between witness fees and current wage levels. No citizen should have to make a personal sacrifice because of innocent involvement in a crime. Cooperation is crucial to the successful operation of the system. The public is being sharply criticized for its reluctance to aid victims, to report crimes, and to appear at trials. Considering how the system treats such persons, it is something of a miracle that the police and courts have any public cooperation at all. A survey of witnesses and victims involved in the system should be taken, incorporating their suggestions for fair treatment into the standard procedures. I predict that this will substantially affect the number of crimes reported, public cooperation, and consequently the efficiency of the system.
We should examine the conduct of hearings, especially the treatment of witnesses and the use of rules of evidence. ${ }^{19}$ Ways of reaching the truth that do not penalize or abuse the witnesses should be explored. In rape cases, for example, other countries have established procedures for the private interrogation of the victim. When a child is the victim of sexual molestation, questioning is done by an expert in child psychology rather than by counsel. In Israel this expert is permitted to testify about the facts of the offense, and the victim is spared the court appearance.

Directly related to the treatment of others by the system is the issue of restitution. "To make the victim whole" is a sound principle of negligence law and of justice which conforms to the laymen's view of a simple criminal justice system. Restitution should be an integral part of the system. We have permitted subsidiary issues of the means or manner of restitution to obscure the fundamental issue: we argue about the superficial problems and ignore the basic one. Once the concept of restitution is adopted, the details can be decided. The means should be provided by the convicted person except when he is too poor to do so. Here the state should act as an insurer. When the offender does not have the means, the state should compensate the victim and hold a right of subrogation against the offender.

\section{Conclusion}

Our criminal justice system obviously needs improvement. The typical reform has been single purpose, a

19 Talbot Smith, "Crowded Dockets and the Hearsay Rule," American Bar Association Journal, March 1968, pp. 231-37. 
reaction to a particular situation or set of circumstances. This kind of reform will not produce results that we desire and urgently need. Because of the interrelation of the components of the criminal justice system, a re-examination of the whole must supersede consideration of each independent part. To do this requires systems analysis by a criminal justice generalist, as distinguished from the specialist in law enforcement, or law, or the judiciary, or probation and parole, or correction. Several recent publications have placed an undue emphasis on computer programing for systematic analysis in this field.20 This is an exaggerated reliance upon hardware and seems to impute a mystical wisdom to wired connections. Computers are a sophisticated form of pencil and paper, not a substitute for thought. Systems analysis would apply to the criminal justice system the same kind of orderly, disciplined thought that good lawyers give to their cases. It would provide a background for decisions about alternative choices for the system.

The analysis will assist in determining the direction of objectives and sub-objectives. The execution of these goals will require the following:

1. That we create structures which permit and encourage the participation of individuals within the criminal justice agencies to exchange

20 Cf. Joseph A. Navarro and Jean G. Taylor, "An Application of Systems Analysis to Aid in the Efficient Administration of Justice," Judicature, August-September, 1967, pp. 47-52; Alain C. Enthoven (Assistant Secretary of Defense for Systems Analysis), Hearings of the Committee on Government Operations, U.S. Senate, 90th Congress, first session, 1967: "I think the computer aspect of Systems Analysis has been badly over-emphasized. I rarely talk about computers." information and opinions across organizational and professional lines, and to engage in joint determination of objectives, procedures, and policies; and (b) which permit and encourage citizen participation in the formulation of criminal law and law enforcement policies.

2. That we carefully guard against invisible procedures at all stages of the criminal process.

3. That we give thoughtful attention to the capability of the system for a flexible response at each stage of the process.

4. That the system be balanced so that each of the stages is supportive and so that every person involved in the system receives equal consideration.

5. That substantial research and study of actual results of the present operating procedures be undertaken.

This article suggests that we plan, research, and experiment in terms of larger objectives. I am aware that there are problems of federal, state, and local relationships, of separation of powers, and of tradition. We will continue to respond to urgent situations by specific reforms. When this is done, let us examine those reforms with a broader goal in mind. Let us seek to separate the superficial symptoms and problems from the substance and diligently inquire into the efficacy of existing procedures.

Reform and revision will not be easy. They cannot happen all at once. When directed toward larger objectives, the same kind of dedicated effort which is now directed toward single-purpose reform can and will produce the justice we so urgently desire and of which we are capable. 